\title{
GOUT IN CYANOTIC CONGENITAL HEART DISEASE
}

\author{
BY \\ JANE SOMERVILLE \\ From the Academic Unit, Institute of Cardiology \\ Received July 6, 1960
}

Gout complicating cyanotic congenital heart disease is infrequently recognized. Its occurrence in blood dyscrasias associated with hyperuricæmia is well documented (Glückmann, 1910; Weber, 1934; Barr et al., 1950; Hickling, 1953). In polycythæmia rubra vera, gout occurs in 5 to 9 per cent of patients (Tinney et al., 1945; Videbaëk, 1950; Lawrence, 1955) and the complication has been referred to in secondary polycythæmia (Gutman, 1953) and investigated in a man aged 50 with severe cyanotic congenital heart disease (Yü et al., 1953). However, relatively few patients with severe cyanotic heart disease and polycythæmia extreme enough to lead to hyperuricæmia survive into adult life when the manifestations of gout are most common. The purpose of this paper is to draw attention to the occurrence of gout with cyanotic congenital heart disease, for it may be overlooked as a cause of arthritis in such patients.

\section{MATERIAL}

Nine cases of gout complicating cyanotic congenital heart disease were seen in a period of five years at two hospitals. Table 1 summarizes the findings. There were 8 men and 1 woman, a similar sex incidence to hereditary gout in which 96 per cent of the affected patients are men (Kaegi, 1955). Eight patients had manifestations of gout before the age of 40, an earlier age incidence than in hereditary gout. The administration of diuretics may precipitate gout (Wood, 1956) but this was not a factor in these patients.

Tophi were present in 7 patients, 6 of whom had arthritis also. In 2 patients tophi were known to precede the first attack of arthritis by one to two years. The joints involved and the radiographic appearances were the same as in hereditary gout.

Cyanosis of at least ten years duration, polycythæmia, and a raised hæmoglobin were common to all patients. The cardiac lesions were tetralogy of Fallot (4 cases), Ebstein's disease ( 2 cases), infundibular stenosis and reversed interatrial shunt (1 case), transposition of the great vessels with pulmonary hypertension ( 1 case), and pulmonary stenosis and single ventricle (1 case). In all patients the leucocyte count was normal.

Serum uric acid and hæmoglobin estimations were performed in 57 patients with cyanotic congenital heart disease who had no manifestations of gout, for comparison with the findings in gouty patients. Thirty-eight of these patients were between 16 and 52 years of age and 18 were under 16. The results are shown in Fig. 1 and 2 and discussed below.

\section{Discussion}

Patients with primary polycythæmia rubra vera have an increased uric acid production which may lead to hyperuricæmia. When the elevation of the blood uric acid persists over a long period of time, precipitation into joints may occur and lead to gout, which presents the same form as the hereditary condition (Talbott, 1957). The same situation may be present with secondary polycythæmia although this is not associated with leucocytosis which therefore had not contributed to 
TABLE 1

Findings in Patients with Cyanotic Congenital Heart Disease and Gout

\begin{tabular}{|c|c|c|c|c|c|c|c|c|c|c|c|c|c|c|c|}
\hline 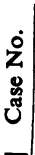 & 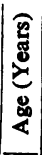 & ׁ & Lesion & $\underset{\%}{\mathrm{Hb} .}$ & 롱 & $\begin{array}{c}\text { Site } \\
\text { of } \\
\text { tophi }\end{array}$ & 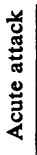 & 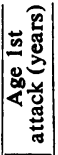 & $\begin{array}{l}\text { Site of } \\
\text { 1st attack }\end{array}$ & $\begin{array}{c}\text { First } \\
\text { diagnosis }\end{array}$ & $\begin{array}{l}\text { Acute } \\
\text { attacks: } \\
\text { uric acid } \\
\text { mg. per } \\
100 \mathrm{ml} \text {. }\end{array}$ & $\begin{array}{l}\text { Between } \\
\text { attacks: } \\
\text { uric acid } \\
\text { mg. per } \\
100 \mathrm{ml} \text {. }\end{array}$ & $\begin{array}{c}\text { Other } \\
\text { joints } \\
\text { involved }\end{array}$ & $\begin{array}{c}\text { Albu- } \\
\text { minuria }\end{array}$ & $\begin{array}{c}\text { Kidney } \\
\text { histology }\end{array}$ \\
\hline 1 & 34 & $\mathbf{M}$ & $\begin{array}{l}\text { Infundibular } \\
\text { stenosis }\end{array}$ & 160 & + & Ears & + & 30 & L. Ankle & $\begin{array}{l}\text { Rheumatoid } \\
\text { arthritis }\end{array}$ & $13 \cdot 2$ & $8 \cdot 4$ & Knees & + & Congestion \\
\hline 2 & 26 & $\mathbf{M}$ & $\begin{array}{l}\text { Eisenmenger, } \\
\text { Transposition } \\
\text { of great } \\
\text { vessels }\end{array}$ & 150 & + & $\begin{array}{l}\text { Hands } \\
\text { Ears } \\
\text { Fingers }\end{array}$ & + & 23 & $\begin{array}{l}\text { P.I.P. } \\
\text { Thumb }\end{array}$ & Gout & $9 \cdot 6$ & $6 \cdot 7$ & $\begin{array}{l}\text { Metacarpal } \\
\text { phalangeal } \\
\text { Elbows } \\
\text { Metatarsal } \\
\text { phalangeal }\end{array}$ & + & $\cdots$ \\
\hline 3 & 18 & $\mathbf{M}$ & Fallot & 148 & + & L. Ear & - & 16 & R. Ankle & $\begin{array}{l}\text { ?Rheumatic } \\
\text { fever }\end{array}$ & - & 6.4 & L. Knee & + & Congestion \\
\hline 4 & 20 & $\mathbf{M}$ & Fallot & 140 & + & R. Ear & - & .. & . & $\cdots$ & . & $7 \cdot 1$ & $\ldots$ & $+t$ & $\ldots$ \\
\hline 5 & 46 & $\mathbf{M}$ & $\begin{array}{r}\text { Ebstein's } \\
\text { disease }\end{array}$ & 146 & + & $\begin{array}{l}\text { Ears } \\
\text { Fingers }\end{array}$ & + & 35 & $\begin{array}{l}\text { P.I.P. } \\
\text { Forefinger }\end{array}$ & Whitlow & - & $6 \cdot 4$ & $\begin{array}{l}\text { Metatarsal } \\
\text { phalangeal } \\
\text { Elbow }\end{array}$ & - & $\cdots$ \\
\hline 6 & 40 & $\mathbf{F}$ & $\begin{array}{r}\text { Ebstein's } \\
\text { disease }\end{array}$ & 135 & - & . & + & 30 & $\begin{array}{l}\text { 1st meta- } \\
\text { tarsal } \\
\text { phalangeal } \\
\text { joint }\end{array}$ & Gout & $5 \cdot 9$ & $5 \cdot 4$ & . & - & $\begin{array}{c}\text { Slight arterial } \\
\text { narrowing } \\
\text { from intimal } \\
\text { proliferation }\end{array}$ \\
\hline 7 & 69 & $\mathbf{M}$ & $\begin{array}{l}\text { Transposition, } \\
\text { P.V.S., } \\
\text { Single } \\
\text { ventricle }\end{array}$ & 148 & - & .. & + & 55 & L. Wrist & $\begin{array}{r}\text { Traumatic } \\
\text { arthritis }\end{array}$ & $12 \cdot 5$ & $7 \cdot 6$ & $\begin{array}{l}\text { Elbow } \\
\text { ? Shoulder }\end{array}$ & + & $\begin{array}{l}\text { Arterial thick- } \\
\text { ening as } \\
\text { found in } \\
\text { essential } \\
\text { hypertension }\end{array}$ \\
\hline 8 & 46 & $\mathbf{M}$ & $\begin{array}{l}\text { Pulmonary } \\
\text { atresia }\end{array}$ & 158 & + & $\begin{array}{l}\text { Ears } \\
\text { Finger } \\
\text { Elbow }\end{array}$ & + & 36 & $\begin{array}{l}\text { 1st meta- } \\
\text { tarsal } \\
\text { phalangeal } \\
\text { joint }\end{array}$ & Gout & $11 \cdot 5$ & $8 \cdot 0$ & $\begin{array}{l}\text { P.I.P. } \\
\text { Ankle } \\
\text { Metacarpal } \\
\text { phalangeal }\end{array}$ & + & .. \\
\hline 9 & 26 & $\mathbf{M}$ & $\begin{array}{l}\text { Tricuspid } \\
\text { stenosis, } \\
\text { Fallot }\end{array}$ & 158 & + & $\begin{array}{l}\text { Ears } \\
\text { Fingers }\end{array}$ & + & 17 & $\begin{array}{l}\text { P.I.P. } \\
\text { Forefinger }\end{array}$ & $\begin{array}{l}\text { Whitlow } \\
\text { Dermatitis } \\
\text { artefacta }\end{array}$ & $8 \cdot 0$ & $6 \cdot 2$ & $\begin{array}{l}\text { Thumb } \\
\text { Wrist } \\
\text { Ankles } \\
\text { Metatarsal } \\
\text { phalangeal }\end{array}$ & $\begin{array}{c}+++ \\
\text { (hyaline } \\
\text { casts } \\
\text { cellular } \\
\text { casts) }\end{array}$ & $\begin{array}{l}\text { Chronic diffuse } \\
\text { glomerular } \\
\text { nephritis. } \\
\text { Cortical lipid } \\
\text { deposits }\end{array}$ \\
\hline
\end{tabular}

P.I.P.-Proximal interphalangeal joint. P.V.S.-Pulmonary valve stenosis.

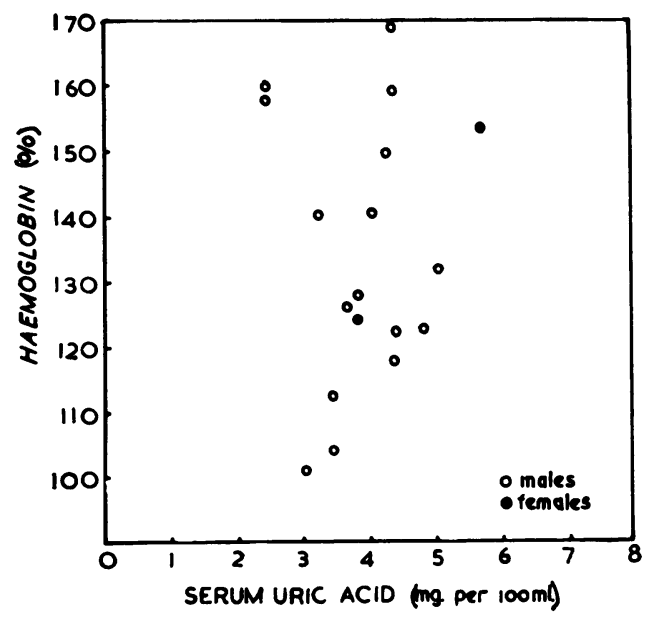

Fig. 1.-Relationship of hæmoglobin to serum uric acid in patients with cyanotic congenital heart disease under 16 years of age.

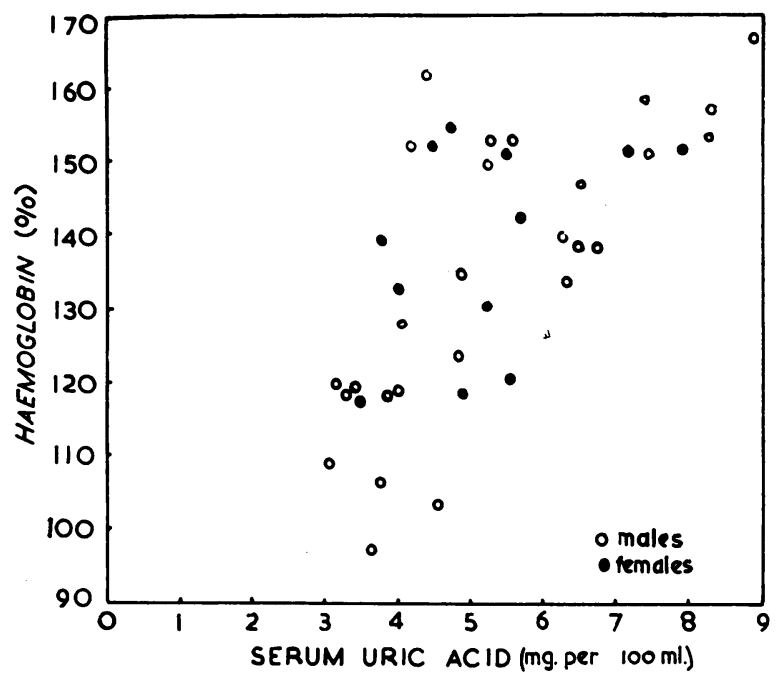

FIG. 2.-Relationship of hæmoglobin to serum uric acid in patients with cyanotic congenital heart disease over 16 years of age. 
uric acid production. Thus, in secondary polycythæmia, hyperuricæmia and its complications may be expected to occur less frequently than in polycythæmia rubra vera.

The incidence of gout in secondary polycythæmia is not known. The nine cases here reported have been found in about 400 patients with cyanotic congenital heart disease, an incidence of approximately 2 per cent which is five times the probable incidence of 0.2 to 0.5 per cent of the general population. If only adult cyanotic patients were considered (that is over 16 years of age), the incidence of gout would be much greater since all patients in the present series were adults and the majority of the 400 cyanotic patients with congenital heart disease were infants or children. This fact, as well as the uniform absence of a family history of gout make it unlikely that gout occurring with cyanotic congenital heart disease is a chance association of two diseases.

The normal serum uric acid in men is 5.5-6 mg. per $100 \mathrm{ml}$. (Talbott, 1957) and $0.5 \mathrm{mg}$. less in women (Smyth et al., 1948). Hyperuriæmia was present during and between attacks of gout in the nine patients. There are a number of factors that influence the development of a raised serum uric acid in these patients.

The hæmoglobin level was 130 per cent or more at the time of the first attack of gout in all the patients. Cyanosis had been present for at least ten years in each and seven of them stated that their colour had deepened 3 to 5 years before the appearance of gout. It is, therefore, likely that the high hæmoglobin levels were present over this period. It is known that in primary polycythæmia there is no correlation between the height of the hæmoglobin and level of serum uric acid (Tinney et al., 1945) and no correlation was found between these measurements in patients under 16 with cyanotic congenital heart disease who did not have gout (Fig. 1). By contrast in the 57 patients over 16, 10 of the 25 with hæmoglobin levels over 130 per cent had a raised serum uric acid (Fig. 2). The remaining 31 patients with a lower hæmoglobin showed no tendency to elevation of the serum uric acid. It appears that there is a correlation between hæmoglobin and serum uric acid in certain of the adult patients with secondary polycythæmia. None of these patients with hyperuricæmia had any manifestations of gout but it is likely that if they survive, gout will develop in some of them.

Comparison of Fig. 1 and 2 show that the age of the patient with secondary polycythæmia appears to influence the development of hyperuricæmia. Only one patient under 16, a girl of 14 with transposition of the great vessels and pulmonary stenosis, had a raised uric acid of $6.4 \mathrm{mg}$. per 100 ml., whereas ten of those over 16 had hyperuricæmia. Gout was not seen below the age of 18, and five patients were over 30 when the first signs appeared. In normal people studied from infancy to adolescence, it has been shown that the serum uric acid increases with age (Hoëffel and Moriarty, 1924; Starkenstein, 1937). Patients with secondary polycythæmia who have no evidence of aberrant uric acid metabolism which is found in primary gout (Yü et al., 1956), may behave as normal people and show increase of the serum uric acid with age. It is likely that the initial levels of uric acid are higher than in the normal person, owing to increased uric acid production from red cell formation.

In three of the four patients who had manifestations of gout before the age of 25 there was evidence of primary renal disease, which may be a further factor influencing the development of hyperuricæmia. Cases 4 and 9 had 3 to 5 parts of albumen per $1000 \mathrm{ml}$. with hyaline and cellular casts in the urine and Case 3 had acute nephritis when 12 years old. Histological examination of the kidneys at necropsy in Cases 3 and 9 showed only congestion in the former and bilateral chronic membranous glomerulo-nephritis with cortical lipid deposits in the latter. Kidneys examined at autopsy in Cases 1, 6 and 7 were found to be normal, apart from minor arterial changes in Cases 6 and 7. In none was there evidence of gouty renal lesions. Case 9 was the only patient in whom acute attacks of gout continued when the hæmoglobin was below 130 per cent. Following a left Blalock-Taussig anastomosis, cyanosis diminished and the hæmoglobin fell from 158 to 115 per cent. Three years later gout recurred for the first time after operation when the hæmoglobin was 115 per cent and serum uric acid $7.9 \mathrm{mg}$. per $100 \mathrm{ml}$. It is likely that the hyperuricæmia and gout developed with a comparatively low hæmoglobin because of impaiied renal uric acid clearance. The primary cardiac disease may have been associated with reduced renal blood flow providing a further factor in precipitating hyperuricæmia and gout. 
The commonest cyanotic congenital heart disease associated with gout was the tetralogy of Fallot which was present in four patients. It is the commonest congenital cyanotic heart disease to be found in patients who survive to adult life, a fact that accounts for its frequency in this series. Gout was found in only one patient with the Eisenmenger reaction. These patients do not usually have a severe secondary polycythæmia except in terminal stages unless the associated lesion is transposition of the great vessels (Case 2), and this may account for the infrequency of gout complicating the condition.

Symptomatic treatment for gout in the cyanotic cardiac patients is the same as for the hereditary condition. Acute attacks respond to colchicine. Benemid and salicylates may reduce the number of attacks and the pain of chronic arthritis. Venesection was most beneficial in prolonging the length of time between attacks but it should be undertaken with caution, as the polycythæmia is compensatory. In three patients the serum uric acid was reduced following venesection. The mechanism for this is uncertain but it is presumed that the temporary reduction in uric acid contributes to freedom from attacks. Surgical correction of the anatomical defect is the ideal treatment but operation in these elderly polycythæmic congenital cyanotic patients carries a high mortality.

The diagnosis of the first attack of acute arthritis was frequently incorrect. This is understandable as gout in a patient below the age of $\mathbf{4 0}$ without any family history is rare. However, in view of the possibility of longstanding hyperuricæmia in adult patients with cyanotic congenital heart disease, gout is a likely complication and should be remembered in differential diagnosis.

\section{SUMMARY}

Gout complicating cyanotic congenital heart disease is described in 9 patients, 8 men and 1 woman. All were adults, the youngest being 18 and the oldest 69 . Fallot's tetralogy was present in 4 of the 9 patients. The incidence of gout in cyanotic congenital heart disease is greater than in the general population. In all the patients studied, the hæmoglobin was over 130 per cent and the serum uric acid more than $6 \mathrm{mg}$. per $100 \mathrm{ml}$. at the time of the first attack. The development of gout is related to the degree of elevation of hæmoglobin and to the age of the patient. The presence of renal disease may be responsible for its occurrence particularly in patients under 25 .

I am indebted to Dr. Charles Baker, Sir Russell Brock, Dr. Ralph Kauntze, and Dr. Paul Wood for allowing me to include their cases and to Dr. E. Lawson McDonald for his helpful criticism. I wish to thank Dr. A. K. Missen for the histological report on the kidneys of Case 9 and Dr. Reginald Hudson for the report in Case 7 . I am particularly grateful to the Department of Clinical Pathology, Guy's Hospital, and the Pathology Department, National Heart Hospital, for hæmoglobin and serum uric acid estimations.

\section{REFERENCES}

Barr, D. P., Reader, G. G., and Wheeler, C. H. (1950). Ann. intern. Med., 32, 6.

Glückmann, S. (1910). Leukaemia and Gout. Inaugural Dissertation. Berlin, Blanké.

Gutman, A. B. (1953). Ann. intern. Med., 39, 1062.

Hickling, R. A. (1953). Lancet, 1, 57.

Hoëffel, G. N., and Moriarty, M. E. (1924). Amer. J. Dis. Child., 27, 64.

Kaegi, P. (1955). Schweiz. med. Wschr., 85, 698.

Lawrence, J. H. (1955). Polycythamia. Grune and Stratton, New York and London.

Smyth, C. J., Cotterman, C. W., and Freyberg, R. H. (1948). J. clin. Invest., 27, 749.

Starkenstein, E. (1937). Arch. exp. Path. Pharmak., 187, 684.

Talbott, J. H. (1957). Gout. Grune and Stratton, New York and London.

Tinney, W. S., Polley, H. F., Hall, B. E., and Giffin, H. Z. (1945). Proc. Mayo Clin., $20,49$.

Videbaëk, A. (1950). Acta med. Scand., 138, 179.

Weber, F. P. (1934). Lancet, 2, 808.

Wood, P. (1956). Diseases of the Heart and Circulation. Eyre and Spottiswoode, London.

Yü, T. F., Wasserman, L. R., Benedict, J. R., Bien, E. J., Gutman, A. B., and Stetten, D. (1953). Amer. J. Med., 15, 845 .

- _., Weissmann, B., Sharney, L., Kupfer, S., and Gutman, A. B. (1956). Amer. J. Med., $21,901$. 